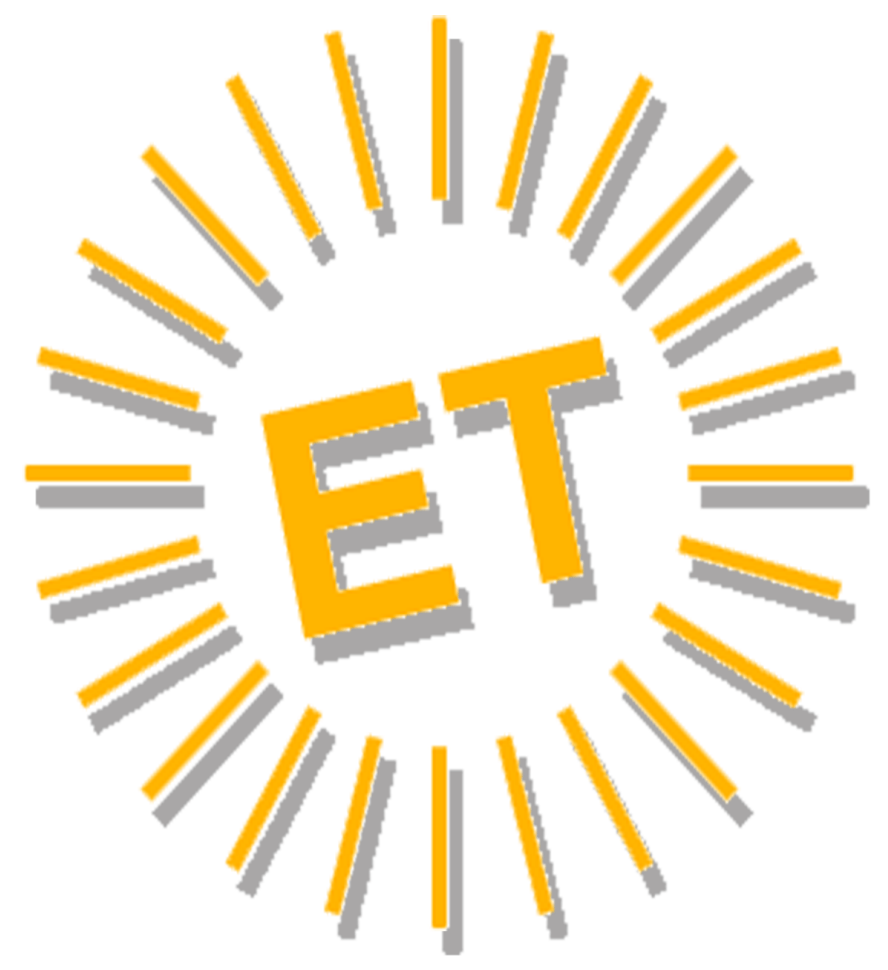




\section{Editorial Team}

Editor in Chief

Alfonso Vargas-Sánchez, University of Huelva, Spain

\section{Associate Editor}

T.C. Huan, National Chiayi University, Taiwan

\section{Books Review Editor}

Brendan Paddison, York St. John University, United Kingdom

\section{Secretariat}

Elena García de Soto, University of Huelva, Spain

Cinta Borrero-Domínguez, University of Huelva, Spain

\section{Style reviewer and text editor}

Anestis Fotiadis, I-SHOU University, Taiwan, Province of China

\section{Editorial Board}

José Manuel Alcaraz, Murdoch University, Australia Mario Castellanos-Verdugo, University of Seville, Spain José Antonio Fraiz-Brea, University of Vigo, Spain José Manuel Hernández-Mogollón, University of Extremadura, Spain

Shaul Krakover, Ben Gurion University, Israel Jean Pierre Levy-Mangin, University of Quebec, Canada Tomás López-Guzmán, University of Córdoba, Spain Yasuo Ohe, Chiba University, Japón Mirko Perano, University of Salerno, Italy María de los Ángeles Plaza-Mejía, University of Huelva, Spain Nuria Porras-Bueno, University of Huelva, Spain João Albino Silva, Algarve University, Portugal

\section{Advisory Board (Spanish Members)}

César Camisón-Zornoza, Uniersity of Valencia, Spain Enrique Claver-Cortés, University of Alicante, Spain María Teresa Fernández-Alles, University of Cádiz, Spain José Luis Galán-González, University of Seville, Spain Félix Grande-Torraleja, University of Jaén, España Antonio Leal-Millán, University of Seville, Spain Inmaculada Martín-Rojo, University of Málaga, Spain Antonio Manuel Martínez-López, University of Huelva, Spain Francisco José Martínez-López, University of Huelva, Rector, Spain

Pablo A. Muñoz-Gallego, University of Salamanca, Spain
Francisco Riquel-Ligero, University of Huelva, Spain José Miguel Rodríguez-Antón, Autonomous University of Madrid, Spain

Sandra Sanchez-Cañizares, University of Cordoba, Spain Josep Francesc Valls-Giménez, ESADE, Spain

\section{Advisory Board (Other European Members)}

Paulo Aguas, University of Algarve, Portugal Gustavo Barresi, University of Messina, Italy Carlos Costa, Aveiro University, Portugal Salvatore Esposito de Falco, University of Rome "La Sapienza", Italy

Sheila Flanagan, Dublín Institute of Technology, Ireland Tania Gorcheva, Tsenov Academy of Economics, Bulgaria Tadeja Jere-Lazanski, University of Primorska, Slovenia Metin Kozak, Mugla University, Turkey Álvaro Matias, Lusiada University, Portugal Alfonso Morvillo, National Research Council, Italy Alexandru Nedelea, Stafan cel Mare University of Suceava, Romania

Claudio Nigro, University of Foggia, Italy

Angelo Presenza, University "G. D'Annunzio" of ChietiPescara, Italy

Kanes Rajah, Royal Agricultural University, United Kingdom

\section{Advisory Board (Members from the rest of the world)}

John Allee, American University of Sharjah, United Arab Emirates

Nestor Pedro Braidot, National University of La Plata, Argentina

Roberto Elias Canese, Columbia University, Rector, Paraguay

Luca Casali, Queensland University of Technology, Australia Nimit Chowdhary, Indian Institute of Tourism and Travel Management, India

Steven Chung-chi Wu, National Pingtung University of Science and Technology, Taiwán

Dianne Dredge, Southern Cross University, Australia Daniel Fesenmaier, Temple University, United States

Babu George, Alaska Pacific University, United States Dogan Gursoy, Washington State University, United States Jafar Jafari, University of Wisconsin-Stout, United States Sanggun Lee, Pai Chai University, Korea Republic of Albert Yeh Shangpao, I-SHOU University, Taiwán Pauline Sheldon, University of Hawaii, United States Germán A. Sierra-Anaya, University of Cartagena de Indias, Rector, Colombia Xiaohua Yang, University of San Francisco, United States 


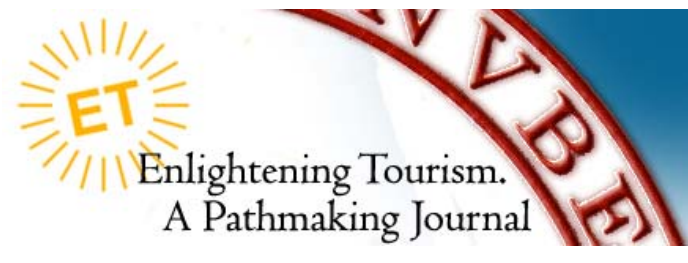

\title{
ECOLOGICAL TOURS AS KEY FOR SUSTAINABLE TOURISM DEVELOPMENT IN TRANSYLVANIA
}

\author{
Tünde Gál \\ Bucharest University of Economic Studies \\ tunde.gal@gmail.com
}

\begin{abstract}
This paper aims to analyse the current state of eco-touristic destinations in the Transylvanian region of Romania, with special attention on the supply and characteristics of ecological tours and its impact on the local community, the environment and the economy. The analysis, in the first place, is based on an exploratory analysis, which identifies the main stakeholders. Afterwards primary data, collected through a structured online questionnaire, present on one hand the approach of the tour operators and tour guides towards the organization of ecological tours, on the other hand, the perception of the customers towards eco-touristic products.

The results indicate that a high percentage of tour operators and tour guides show indifferent attitude towards the organization of ecological tours. However, most of the stakeholders are aware of the fact that in order to preserve our natural sites, on one hand, there is a high need to increase the ecological tour offer and on the other hand, it is crucial to educate both the tourists and the local community. The customers, depending on their socio-economic status and educational level, fall in very different groups when the principles of sustainability are to be kept in practice.
\end{abstract}

KEYWORDS

Ecotourism; Nature-based Tourism; Local Community;

Environmental Education; Sustainability Management; Transylvania.

ECONLIT KEYS

L83; Q26; Z32.

\section{INTRODUCTION}

The current society is undergoing a period marked by major changes, caused by global environmental problems and environmental pressures. According to the 
UNWTO (2017), over the past six decades, tourism has experienced continued expansion and diversification to become one of the largest and fastest-growing economic sectors in the world. As well, tourism has become a central platform in many countries' development strategies, being a multi-faced activity that links the economic, social and environmental components of sustainability (Stănciulescu, Diaconescu and Moraru, 2016). Therefore, when planning touristic products and strategies, it is important to consider what Wearing and Neil (2009) highlighted, that despite the multiplier effect, in many cases the negative economic, environmental and social effects of tourism are often not felt directly and are experienced only after the initial positive economic impact and have to be borne by the local communities. In order to solve this problem, destinations need to limit the number of visitors and to promote tourism, which is ecologically sound and sustainable.

As core activity, the tourism sector combines private and public services with local resources and infrastructures with the aim to satisfy multiple consumers' needs (Caputo, Perano, and Mamuti, 2017). Nevertheless, Buckley (2012) underlines, that tourism is an economic sector strongly dependent on the environment for its development because of the multimodal relationship between the two phenomena, the environment being both subject and object of the economic activity. Therefore, when we decide to make some areas used for tourism, and consequently, to exploit the territory as a basic resource of economic activity, this implicates, inevitably an environmental modification that on the basis of management procedures must be expressed in "imbalance" (Wearing and Neil, 2009). As consequence, it is urgent to make efforts to maintain an equilibrium among the different components of territorial context, in order to guarantee the long-term use, productivity, and sustainability of destinations (Buckley, 2012). This results in a high need for developing touristic products with low environmental and social impacts, including ecological tours.

Romania has a rich eco-touristic potential (INCDT, 2015), so the development and promotion of this form of tourism have immense capabilities, but some high potential regions, as it is Transylvania, could lose their main attraction - untouched nature - if there is no proper regulation, will and action both at national and municipal levels. Before 1989, Romania used to be an important tourist destination for the EasternEuropean market. Touristic products promoted were: seaside, spa, cultural circuits, and also the monasteries in Northern Moldavia and Bucovina (Coroș and Negrușa, 
2014). Once the Iron Curtain was eliminated, Romania entered the international tourist market due to its rich natural and cultural heritage, which offers an excellent chance of transforming the country into a special attraction on the ecotourism market. Romania has some of the largest areas with virgin forests in Europe, the large majority of European brown bears, wolves and globally outstanding flora and fauna with the most important part of these resources being in the Transylvanian region, the largest region in Romania, circled by the Carpathian mountains. However, the biodiversity is under serious threat due to unsustainable exploitation, pollution, and land-use changes. All these, highly affecting Europe's last virgin forests, the biodiversity and the unique large carnivore population (Candrea and Herțanu, 2015).

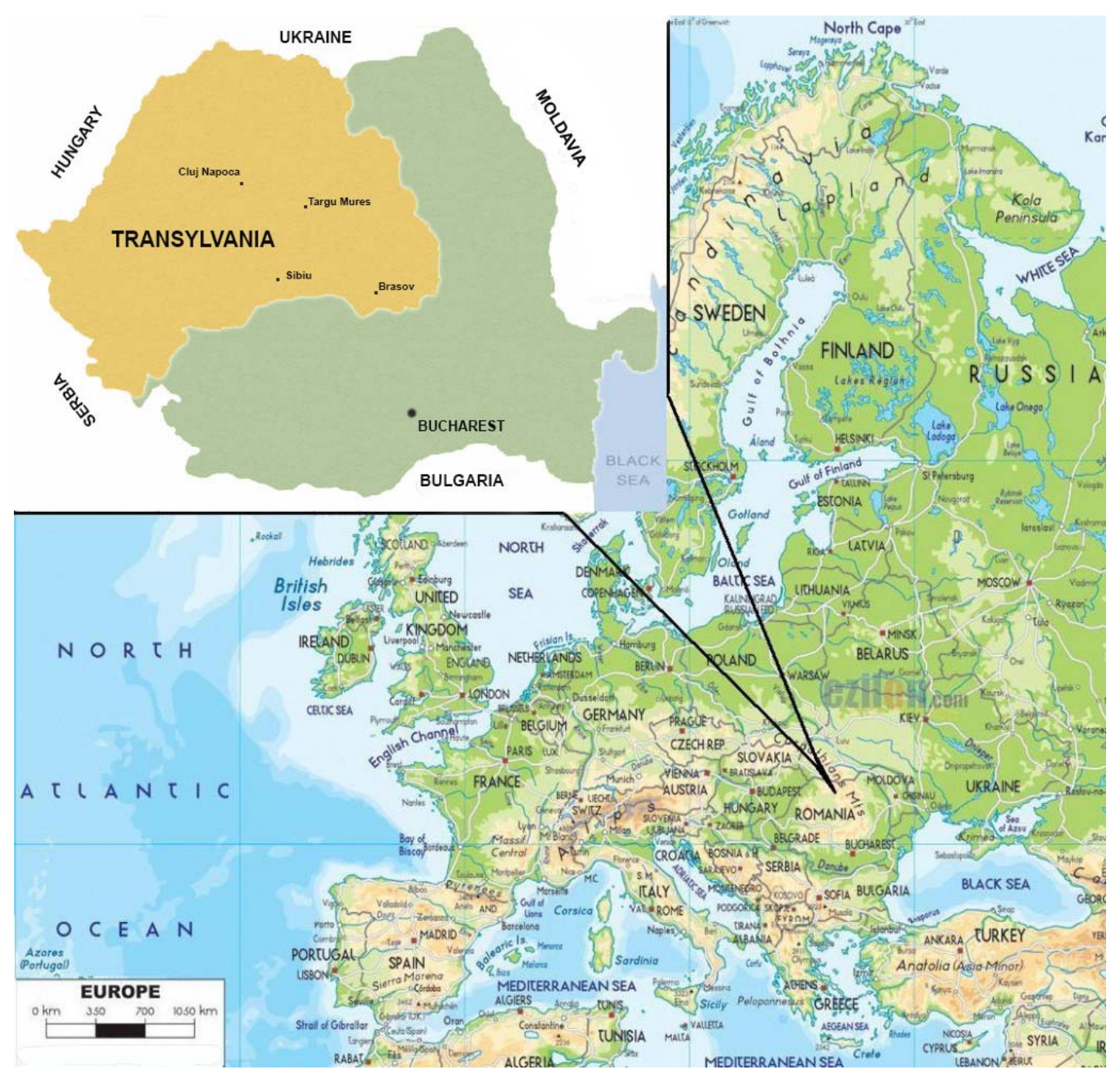

Figure 1: Transylvania region, as part of Romania and Europe Source: http://maps.europe.Romania 
In the last decade, there have been some endeavours at the national level to identify and protect these natural areas, mostly done by NGOs. In partnerships with the National Institute for Research and Development in Tourism (INCDT) and the Association of Ecotourism in Romania (AER) a new framework has been developed to identify and certify eco-touristic destinations in Romania. The certification programme has been developed based on the Global Sustainable Tourism Criteria (GSTC) and the European Eco-Tourism Labelling Standard (EETLS) and supports communities that are investing in sustainable tourism practices that respect the local natural heritage and cultural traditions. Sustainable development of Romanian local communities through ecotourism and rural tourism represents a requirement and at the same time a tendency of contemporary evolution (Nistoreanu and Dorobantu, 2012). Ecotourism is becoming, for some potential regions one of the factors that ensure a high quality of life and the well-being of local communities, representing an engine of progress. Romania has a valuable ecotourism potential that can be valorised by adopting an efficient management in the process of the sustainable development of a destination, ensuring a high level of quality for ecotourism products, but also a balance between protection and valorisation of the tourism resources.

In the circumstances presented above, and considering the current international trend regarding the growing appeal of nature-related destinations and taking in consideration that there are a low number of scientific papers on this highly important subject about the region, the current paper aims to investigate the current state of eco-touristic destinations in the Transylvanian region of Romania, following research question: Are ecological tours the key tourism products towards a sustainable tourism development in Transylvania?

Three dimensions can represent the main essence of the ecotourism concept: nature-based, environmentally educated and sustainably managed (Weaver, 2001). In order to answer the research question, these three dimensions are briefly analysed, followed by the results of the online questionnaire which focused on the supply and characteristics of ecological tours and its impact on the local community, the environment and the economy through the perspective of inbound tour-operators, tourism promotion associations and organizations, the most important stakeholders when talking about tour supply with the aim to provide answers to the research question presented above. 


\section{LITERATURE REVIEW}

The concept of ecotourism has been perhaps the most dramatic outcome of the environmental movements of the last four decades, and as mentioned above, three dimensions can represent the main essence of the concept: nature-based, environmentally educated and sustainably managed (Weaver, 2001).

\section{1) NATURE-BASED}

At first, in the 1980s ecotourism was perceived largely as visitation to natural areas for the purposes of enjoyment and education (Ceballos-Lascurain, 1987), and defined it as: 'traveling to relatively undisturbed or uncontaminated natural areas with the specific objective of studying, admiring, and enjoying the scenery and its wild plants and animals, as well as any existing cultural manifestations found in these areas'. Later, Ziffer (1989) describes ecotourism as a form of tourism, stimulated primarily by the natural history and indigenous cultures of an area, and one that inspires in visitors the spirit of appreciation, participation, and sensitivity. Goodwin (1998:228) gives a wider definition, underlining the importance of community implication: 'low impact nature tourism which contributes to the maintenance of species and habitats either directly through a contribution to conservation and/or indirectly by providing revenue to the local community sufficient for local people to value, and therefore protect their wildlife heritage area as a source of income'.

As underlined by Wearing and Neil (2009), the natural environment is central to ecotourism which has a focus on biological and physical features. The conservation of natural areas and sustainable resource management is therefore essential to the planning, development, and management of ecotourism. This is in part a reflection of increasing recognition among industry and government, that nature-based tourism can only be sustained in the long term if a principled and proactive supply-side management approach is adopted (Weaver et al, 2001). Ecological tours, being an important component of ecotourism, operate on a small scale, thus require littlespecialised infrastructure and therefore do not contribute to environmental damaging, 
on which ecotourism, and all forms of tourism, depend (Wearing and Neil, 2009). Fortunately, at the beginning of the 1990's, after much discussion at international conferences, conservation was regarded as an essential part of any definition of ecotourism, the 'eco' prefix being derived from the word 'ecology'. Thus, to be considered as ecotourism, an activity or experience must positively contribute to the environment: 'if the environment has not at least achieved a net benefit towards its sustainability and ecological integrity, then the activity is not ecotourism' (Butler, 1991:4).

\section{2) ENVIRONMENTAL EDUCATIONAL}

Valentine (1991) drew attention to the 'two-way interaction' between ecotourism and the environment upon which it depends, by suggesting that one characteristic of ecotourism is that it is both contributory to conservation as well as the enjoyment of nature. Ecotourism involves a focus on nature as the primary motivation for travel, to further knowledge and awareness of nature. However, it also involves the notion that the activity of ecotourism must positively contribute to conservation in the destination area or host community. Planning for ecotourism is based on resource limitations as ecotourism opportunities will be lost if the resilience of an area and the ability of its communities to absorb impact are exceeded, or if its biodiversity and physical appearance are altered significantly. Therefore an essential feature of ecotourism is sustainability and sustainable development by implication.

As underlined by Buckley (1994) attitude to nature, deliberate behaviour to minimize impacts (individual tourists), education or regulation of clients to change attitudes and/or behaviour (tourism service provider) is essential through guides, education programmes, tour package and group ethic. Although interpretation can reduce impacts, only if stringent conditions are met, otherwise, interpretation does not change either attitudes or impacts (Buckely, 2012). Asked to behave responsibly, individuals find often in a conflict situation between their short-term personal gains and the long-term societal needs, such as concerns for sustainable development (Budeanu, 2007). Although considered the most difficult ones to solve, such societal traps must be broken in order to achieve a sustainable future for all (Bell et al., 1996).

When talking about the consumers of eco-touristic products and their typology, 
based on previous investigations related to their preferences, motivations and behaviour, we can state that ecotourists can be characterized by high level of education, with an income level above average (Eagles and Cascagnette, 1995; Wight, 1996) and being more active on a daily basis than usual. According to the scientific literature, they were issued different theories on tourism market segmentation in order to identify ecotourists and divide them into distinct subgroups. From the perspective of the current study, it is highlighted how Lindberg (1991) divided the market into four segments of ecotourism, based on their behaviour and motivations: the first group being the 'hardcore' ecotourists, composed by scientists or people traveling for educational purposes; the second named as 'dedicated', which are people who take trips specifically to see protected areas and who want to understand local natural and cultural history; "mainstream" ecotourists are people who visit famous natural destinations; and "casual" ecotourists are tourists who come into contact with nature during a holiday, incidentally.

\section{3) SUSTAINABLY MANAGED}

The most cited definition of the concept of sustainable development was given by the Brundtland Report already in 1987 (WCED, 1987): "development that meets the needs of the present without compromising the ability of future generations to meet their own needs", in many sectors of the economy, including tourism, it is hardly put into practice. The fundamental concern of sustainability is that aggregate human impacts threaten the survival of humans and the ecosystem services on which they depend (Buckley, 2012). As highlighted by Stănciulescu (2000), the purpose of tourism development must always balance the needs of tourists with the needs of destinations and their hosts.

The main priorities of sustainable development regarding the ecotourism concept means: promoting the concept and development of ecotourism for the support of nature conservation at the local, regional and national level, promoting the natural and traditional values that respect nature, involving local communities in ecotourism services and infrastructure development, promoting the ecotourism as a tool for income generation, and encouraging tour operators to use local resources, developing and maintaining a quality service system in ecotourism (Nistoreanu and 
Dorobantu, 2012). It has to be taken into consideration, that ecotourism does not mean only ecological sustainability, but also cultural sustainability as well, tourism, which does not damage the culture of the host community, encouraging a respect for the cultural realities experienced by the tourists through education and organized 'encounters' (Wearing and Neil, 2009). The Community Based Tourism (CBT) term emerged in the mid-90s, being practiced on a small scale, implying interactions between visitors and the host community, and it is suitable to and applied mostly in rural and regional areas. It is a form of "local" tourism, favouring local service providers and contributes to each of the "three pillars of sustainability" to supply social, economic and environmental benefits (Stănciulescu, Diaconescu and Moraru, 2016).

At local scale, tourism can generate economic growth, but at large scale, prosperity increases environmental impact and, especially in less wealthy nations, there may often be cultural, historical and socioeconomic differences between residents and international tourists, and internal divisions within communities (Buckley, 2012). Few tourists select sustainable products specifically (Budeanu, 2007); they expect good environmental management routinely (Mair and Jago 2010). Also, most tourism enterprises adopt only those sustainability practices that improve profits or public relations; currently, there are few individual commercial tourism enterprises with positive triple bottom lines, including positive net contributions to local communities and to conservation (Buckley, 2012).

Weaver et al. (2001) offers a chronological overview of the evolution of ecotourism definition over time, and it is important to highlight that the meaning of ecotourism had by the turn of the 21st century broadened to incorporate environmental conservation, social inclusion, cultural preservation, human rights, ethical issues and economic development (Donohoe and Needham, 2006; Fennell, 2015). According to The International Ecotourism Society (TIES), ecotourism means: "responsible travel to natural areas that conserves the environment, sustains the well-being of the local people, and involves interpretation and education". This definition by TIES is also supported by the IUCN explanation of ecotourism, adopted from Ceballos-Lascuráin (1996), which describes ecotourism as environmentally responsible travel and visitation to natural areas, with the purpose of enjoying and appreciating nature and other cultural features, as well as promoting conservation, minimising visitor impact 
and providing for beneficially active socio-economic involvement of local people (Ceballos-Lascuráin, 1996). According to the World Travel and Tourism Council (WTTC, 2017), nature-based tourism is an important economic component of the entire tourism market, making up more than $25 \%$ of the global travel market. As well, the UN General Assembly believes that "ecotourism creates significant opportunities for the conservation, protection and sustainable use of biodiversity and of natural areas" (UN, 2013). Similarly, the International Union for Conservation of Nature (Allam and Naser, 2018) agrees that "ecotourism can be a driver of sustainable development if it is carefully conceived, well-managed and strictly controlled". According to TIES, ecotourism is about uniting conservation, communities and sustainable travel. This means that those who implement, participate in and market ecotourism activities should adopt the following ecotourism principles: minimize physical, social, behavioural, and psychological impacts; build environmental and cultural awareness and respect; provide positive experiences for both visitors and hosts; provide direct financial benefits for conservation; generate financial benefits for both local people and private industry; deliver memorable interpretative experiences to visitors that help raise sensitivity to host countries' political, environmental, and social climates; design, construct and operate low-impact facilities and recognize the rights and spiritual beliefs of the indigenous people in your community and work in partnership with them to create empowerment (TIES, 2015). Therefore ecological tours, or ecotours, are among the most important components of ecotourism, contributing not only to nature preservation but education as well; thus, the concept of ecotourism seeks to conserve the environment, protect local cultures and deliver benefits to both tourists and the host communities.

\section{METHODOLOGY}

Ecological tours are important components of ecotourism, as are operated on a small scale, require little-specialised infrastructure and therefore do not contribute to damaging the environment and can stand as key tourism products for sustainable development. As all regions, to which the main attraction is the untouched nature, like Transylvania, have to focus on preservation, and shift towards nature-based, sustainably managed products, which include environmental education as well, in the 
current study the three main concepts when formulating the framework for ecotourism.

The research area is composed by the 16 counties which belong to the Transylvanian region, all together constituting three development regions out of eight, in Romania: Centre, North-West, and West. The objective of the research was to analyse the current state of eco-touristic sites, with special attention on the supply of ecological tours and its impact on the local community, the environment, and the economy. The first phase of the research was exploratory, identifying the supply of ecological tours in the region, and formulating a database consisting of tour-operators on the inbound tourism market, and associations, foundations, organizations, which not only promote tourism in the region but also offer tours and other activities for tourists. To obtain the relevant primary data necessary for the current research, the above-mentioned suppliers are considered to be the most suitable stakeholders, being involved in the processes of formulation, promotion, and dissemination of the touristic products and being in direct contact with the consumers. Also, they are able to offer the most reliable information about the tourists' perception of ecotours in the region, behavioural patterns and the supply of sustainable touristic products.

The research instrument used was a structured questionnaire, being performed online based on 13 questions (10 closed and 3 open-ended questions), which aimed to identify: Are ecological tours the key tourism products towards a sustainable tourism development in Transylvania? Three dimensions were taken in consideration: nature-based, sustainably managed products, which include environmental education as well. Indicators measured were the evolution and categorisation of the touristic products, the customer acceptance of ecological tours (without motorised vehicles, small groups, including environmental education, sustainably-managed), the willingness of the tourists to be educated and their typology, based on tour-operators' experience. The questionnaire was sent out in an electronic format via directed email to 112 organizations, and completed on a voluntary basis by 66 respondents, representing equally the area and the penetration of organizations. The data was collected between July 2016 and October 2016. 


\section{RESEARCH RESULTS}

The increasing global interest and exponential growth in ecotourism reflect a fundamental shift in the way human beings view and engage with nature (Wearing and Neil, 2009). However, this growth in Romania cannot be characterised as exceptional, due to limited offers and inadequate infrastructure and services. Although, there is no specific data collected on ecotourism, according to the National Institute of Statistics, we can observe an increasing tendency in the last five years in the number of tourists participating in tours organized by travel agencies in mountainous areas, growing from 61.927 in 2013 to 80.595 in 2017 (NIS, 2018).

In the last decade, ecotourism in Romania has evolved systematically as stated by Nistoreanu and Dorobantu (2012) and underpinned as well by the exploratory research. When talking about sustainably managed ecotourism at national level, we observe that there are several eco-touristic destinations developed through strategic partnerships including national authorities and the local communities, but an important part of Romania's and Transylvania's natural and cultural heritage (perhaps some of the most valuable resources) hosted by rural destinations, lack an appropriate infrastructure able to ensure the proper exploitation. Also, the regulations are vague and not well monitored, therefore various motorised vehicles like snowmobiles, ATVs etc. are used in these areas, which are banned in other European countries. Today, in Romania there are eleven certified eco-touristic destinations authorised by the National Authority for Tourism (NAT) out of which four are part of Transylvania: Băile Tușnad and surroundings, Transylvanian Highlands, Zărnești - Piatra Craiului Mountains, and the Surrounding of Sibiu. According to the primary research, namely the identification of the stakeholders, the best represented is Brașov county in the inbound market, followed closely by Sibiu and Cluj counties. All the other counties being represented by a lower number of companies and NGOs, compared to the potential of the area. It is important to mention that although ecological tour offer is significant in Brașov County, a high number of the supply is present due to the controversial "Dracula phenomenon", both from the Romanian and the international market.

As regards the size of the tour operators and NGOs activating in Transylvania are mostly small companies/organisations, hiring tours guides from the respective region, 
presenting the local culture and products, consequently having a positive impact on the local community and the local economy, being in line with the dimension of sustainability managed on the local level.

The second dimension, nature-based, was investigated through the tour supply. According to the research, out of the 66 respondents, $18 \%$ do not offer ecological products at all, $72 \%$ of the organize some kind of ecological tours, which were defined previously as nature-based without motorised vehicles, in small groups, including environmental education. These offers include walking, hiking, cycling, horse-riding, rock-climbing and mountaineering, as well wild-life watching tours on the country-side, also some cultural ones on rural inhabited areas, and can be grouped by popularity as it follows on Figure 1, some operators having more kinds of tours, some focusing on only one or two:

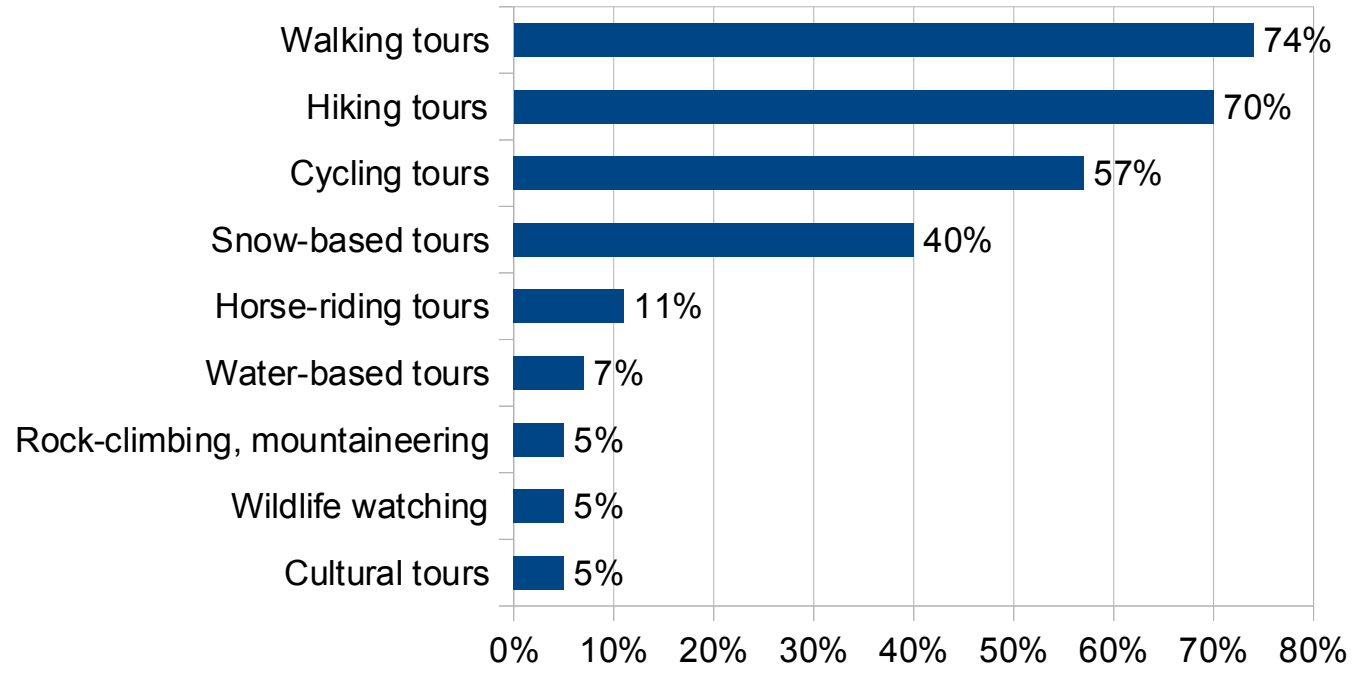

Figure 1: The typology and percentage of the most attractive ecological tours in Transylvania region Source: Designed by the author, based on the online research responses, accessible at the following link: https://docs.google.com/forms/d/1Cu5u4LLrB91/sY7z3ASBX3rfXqith5kBfxZCdILOdSw/edit\#responses

The percentage of the ecological tours in the total offer of the organizations' tours supply is presented in Figure 2, which shows, that $26 \%$ of the respondents organise between $75 \%$ and $100 \%$ of all their tours, as ecological tours, and for another $56 \%$, the ecological tour offer is between $50 \%$ and $75 \%$ of the total tours. 


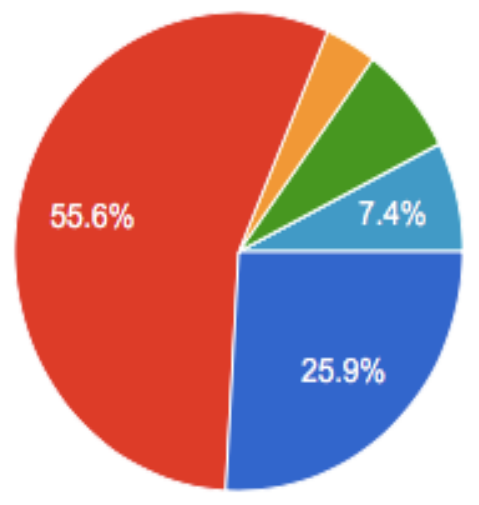

Between $75 \%-100 \%$

Between $50 \%-75 \%$

Between 25\%-50\%

Between $5-25 \%$

Less than $5 \%$

I don't offer such tours

Figure 2: The percentage of the ecological tours in the total offer of the organizations'

Source: Designed by the author, based on the online research responses, accessible at the following link: https://docs.google.com/forms/d/1Cu5u4LLrB91/sY7z3ASBX3rfXqith5kBfxZCdILOdSw/edit\#responses

Henceforth $74 \%$ of the respondents plan to widen their ecological tour offer in the future, which will certainly have a positive impact on the future of the eco-touristic offer in Transylvania. Also, the evolution of the number of the demand in the last five years was rated positive, with the number of consumers asking for ecological tours raising significantly, going up by $25 \%-50 \%$ every year. The eco-labelling system of the AER had as well positive impact, consumers are valuing the ambitions and aspirations of eco-certified activities. $44 \%$ of the respondents are members of AER, and another $40 \%$ are planning to be part of their eco-labelling system, which can project a positive future for the regularisation, standardisation and common promotion of ecological tours in the region.

The third dimension, environmental education in the framework of ecotourism, $76 \%$ of the respondents stated, they always include educational activities in their programmes, $24 \%$ only if the customer is interested in the topic. The most receptive are the consumers active on the job market (between 25-60), followed by the elderly (above 60) and the students (18-25). Taking into consideration the Lindberg grouping of ecotourists presented above, the stakeholders group their customers on the following way: 


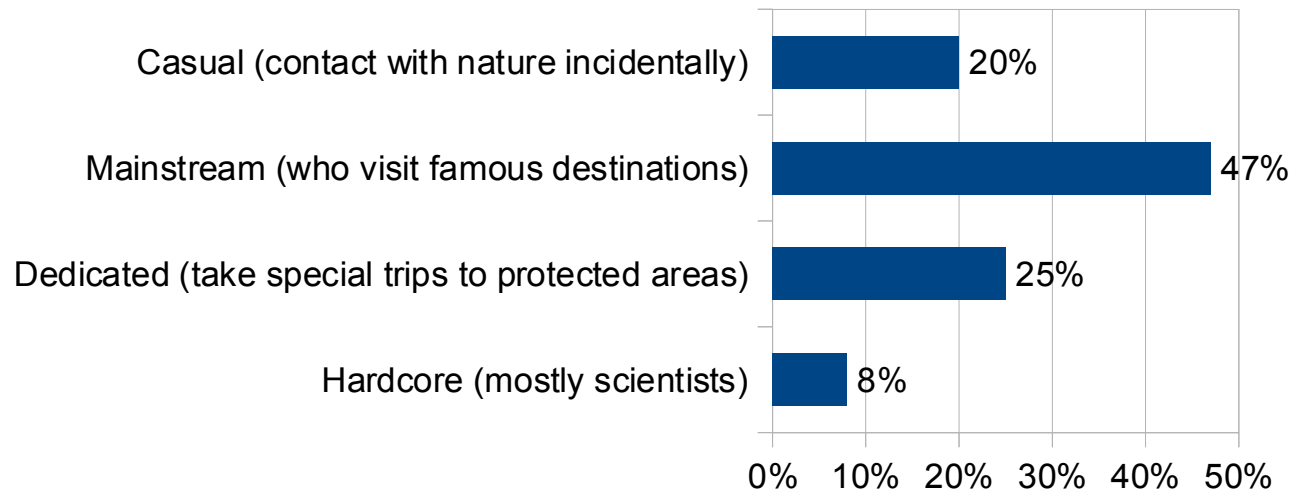

Figure 3: The percentage of customers in Transylvania according to the Lindberg grouping Source: Designed by the author, based on the online research responses, accessible at the following link: https://docs.google.com/forms/d/1Cu5u4LLrB91/sY7z3ASBX3rfXqith5kBfxZCdlLOdSw/edit\#responses

Although there was a significant evolution in the last five years, $70 \%$ of the respondents consider that the ecotourism potential of Transylvania is not exploited properly. The purpose of the study was also the identification of Transylvania's development potential and competitiveness on the ecotourism market, and also the causes of its poor performance until now. Several problems were highlighted to the open questions of the survey, especially, the deforestation, lack of proper protection of the eco-touristic sites, the lack of proper promotion on the international market, lack of national programs to help SMEs in the sector develop their products and infrastructure, not enough support by the central and local authorities, no proper legislation, lack of educational programmes in schools about sustainability in general, lack of well-trained staff, the reduced number of eco-related organizations and brands at the moment and investments in new businesses; promotion and infrastructure (specific trails, modern lodges, etc.) are scarce compared to the country's potential, need for better protection of eco-touristic sites. Transylvania has a huge ecotourism potential and is exploited better than in other parts of Romania, but is mandatory that the local community and small business' leaders understand better the meaning of ecotourism, which means also further need for education. Ecotourism is a great opportunity for Romania to increase its competitiveness in the global market. Unfortunately, regulation seriously falls behind the market evolution and creates barriers for businesses In the case of Transylvania, the illegal wood extraction, has negative effects on the habitat, fauna, biodiversity and the landscape 
overall. The success of ecotourism depends on the conservation of nature. Many parks are threatened, and it is critical for everyone involved with ecotourism to realize that intact natural resources are the foundation.

\section{CONCLUSION AND FURTHER DISCUSSIONS}

Growing environmental concern coupled with an emerging dissatisfaction with mass tourism led to increased demand for nature-based experiences of an alternative nature, ecotourism appealing to a wide range of travellers, of all ages and interests. Ecotourists are a valuable audience for environmental education, but in many sites, opportunities are missed when talking about proper educational services. Whether 'hard-core' nature tourists or 'new' visitors with little background in natural history, can enhance their appreciation of the area through information brochures, exhibits, and proper guidance, but to encourage the development of eco-touristic businesses more attention is needed in Romania from the central and local government. As well, all relevant stakeholders (businesses, local authorities, NGOs, community members) need to be involved in the management and planning of ecotourism development in each destination. Travellers who choose ecotourism are responsible consumers interested in social, economic and environmental sustainability, seeking authentic local experiences and opportunities to give back to the communities they visit. But according to the current research and also stressed by the National Strategy for Ecotourism for 2016-2020 (INCDT, 2015), despite the fact that our country has significant natural resources, with high potential, ecotourism is a segment which faces many problems, such as poor cooperation, relative low promotion at national and international level, poor specific infrastructure development for ecotourism, reduced number of guides with specific knowledge and legal framework which does not correspond with the needs of the local services etc.

The answer to the research question (Are ecological tours the key tourism products towards a sustainable tourism development in Transylvania?) is definitely yes, but in order to develop this sector, ecotourism principles and guidelines need to be applied and reinforced by all stakeholders. Useful guidelines for the role of government in the planning and implementation of sustainable tourism were developed by Ceballos-Lascurain already in 1996 and underlines the following, which 
are still either totally missing, or only partly implemented in Romania and therefore in Transylvania: design and implement educational and awareness programmes to sensitize people to sustainable tourism development issues; ensure that all government departments involved in tourism are briefed on the concept of sustainable development; the respective ministers (e.g. environment and natural resources) should collaborate to achieve sustainable tourism development; undertake area and sector-specific research into the environmental, cultural and economic effects of tourism; increase the costs of environmentally destructive behaviour (fines, fees); decrease the costs of environmentally proactive actions; provide education to make people aware and also show how they can contribute to conservation and also give feedback to people about the consequences of their behaviour.

However the current study provides information on the specificity of inbound touroperators, has a series of limitations, as the exploratory analysis showed a much higher percentage of tour-operators organizing only regular tours and tours with a high negative impact on environment (ex. ATV, 4X4 and motorcycle tours, which are nature-based, but motorised and not sustainable at all) than among the respondents, most of them not interested in nature preservation and ecotourism and are seeking only high profits. Therefore there is a need for further investigation to capture all stakeholders' attitudes, opinions, and intentions regarding the ongoing aspirations for the development of ecotourism in Transylvania.

Overall tourism forecast for the country is positive, so with proper development, marketing, education, protection and monitoring, Transylvania region can achieve a significant increase also in the ecotourism market, although further investigations are required about the profile of the ecotourists visiting the region of Transylvania from customer point of view. An ecological tour can offer sufficient sightseeing, education and nature experiences for tourists, being an important part of the inbound touristic market, and even though the demand is relatively low compared to the potential of the region, shows an increasing trend, and with proper approach from the national and local authorities, the local community and businesses we can predict a positive future for the sustainable development of tourism in Transylvania. 


\section{References}

Allam, K.; Naser, H. Synergy among sustainable development goals and biodiversityrelated conventions in Bahrain. Gland, Switzerland: IUCN (International Union for Conservation of Nature), 2018 [online]. Available at: https://portals.iucn.org/library/sites/library/files/documents/2018-016-En.pdf [accessed 20 June 2018].

Ballantyne, R.; Packer, J. Developing ecotourists' environmentally sustainable behaviour. In R. Ballantyne; J. Packer (eds.). International Handbook on Ecotourism, Edward Elgar Publishing, 2013, pp. 192-202.

Bell, P.A.; Greene, T.C.; Fisher, J.D.; Baum, A.S. Environmental Psychology. Orlando, FL: Holt, Rinehart, and Winston Inc., 1996.

Buckley, R. A framework for ecotourism. Annals of Tourism Research, 21 (3), 1994, pp. 661-665.

Buckley, R. Sustainable tourism, research and reality. Annals of Tourism Research, 39 (2), 2012, pp. 528-546.

Budeanu, A. Sustainable tourist behaviour - A discussion of opportunities for change. International Journal of Consumer Studies, 31(5), 2007, pp. 499-508.

Butler, R.W. Environmental Conservation. Tourism, Environment and Sustainable Development, 18 (3), 1991, pp. 201-209.

Candrea, A.N.; Herțanu, A. Developing ecotourism destinations in Romania. A case study approach. Bulletin of the Transilvania University of Brașov, Series V: Economic Sciences, 8-57 (2), 2015, pp. 163-174.

Caputo, F.; Perano, M.; Mamuti, A. A Macro-Level View of Tourism Sector: Between Smartness and Sustainability. Enlightening Tourism. A Pathmaking Journal, 7 (1), 2017, pp. 36-61. 
Ceballos-Lascurain, H. The future of ecotourism. Mexico Journal, January, 1987, pp. 13-14.

Ceballos-Lascurain, H. Tourism, ecotourism and protected areas. Switzerland, Gland: IUCN (World Conservation Union), 1996.

Coroș, M.M.; Negrușa, A.L. Analysis of Romania's and Transylvania's tourist supply development and performance. Amfiteatru Economic, 16 (8), 2014, pp. 1312-1326.

Donohoe, H.M.; Needham, R.D. Ecotourism: The evolving contemporary definition. Journal of Ecotourism, 5 (3), 2006, pp. 192-210.

Eagles, P.F.; Cascagnette, J.W. Canadian ecotourists: Who are they? Tourism Recreation Research, 20 (1), 1995, pp. 22-28.

Fennell, D.A. A content analysis of ecotourism definitions. Current Issues in Tourism. 4 (5), 2001, pp. 403-421.

Fennell, D.A. Ecotourism. London: Routledge, 2015.

INCDT (Institutul Național de Cercetare-Dezvoltare în Turism). Strategia naţională de dezvoltare a ecoturismului în România (2015) [online]. Available at: https://patrimoniu.gov.ro/images/turismcultural/Romania/Strategie-ecoturism.pdf [accessed 20 June 2018].

Lindberg, K. Policies for maximizing nature tourism's ecological and economic benefit. Washington DC: World Resources Institute, 1991.

Mair, J.; Jago, L. The development of a conceptual model of greening in the business events tourism sector. Journal of Sustainable Tourism, 18 (1), 2010, pp. 77-94 
Miller, J.A. (ed.). The Ecotourism Equation: Measuring the Impacts. Bulletin Series Yale School of Forestry and Environment Studies, 99, 1996. Yale University.

Miller, G.; Twining-Ward, L. Monitoring for a sustainable tourism transition: the challenge of developing and using indicators. Wallingford, Oxfordshire, UK: CABI Publishing, 2005.

National Institute of Statistics. TempoOnline database (2018) [online]. Available at: http://statistici.insse.ro/shop/ [accessed 20 March 2018].

Nistoreanu, P. Ecoturism și turism rural. Bucharest: ASE Publishing House, 2006.

Nistoreanu, P.; Dorobantu, M.R. Rural Tourism and Ecotourism - the Main Priorities in Sustainable Development Orientations of Rural Local Communities in Romania. Economy Transdisciplinarity Cognition, XV (1), 2012, pp. 259-266.

Nistoreanu, P.; Dorobanţu, M.R.; Tुuclea, C.E. The trilateral relationship ecotourism sustainable tourism - slow travel among nature in the line with authentic tourism lovers. Journal of Tourism, 11, 2011, pp. 34-37.

Stănciulescu, G.; Emilian, R.; Tigu, G.; Nistoreanu, P.; Grofu, M.; Tuclea, C. Managementul turismului durabil în ţările riverane Mării Negre, Bucharest: All Beck, 2000.

Stănciulescu, G.; Diaconescu, D.M.; Moraru, R. Considerations on Gastronomic Tourism as a Component of Sustainable Local Development. Amfiteatru Economic, 18 (10), 2016, pp. 999-1014.

The Association of Ecotourism in Romania (AER). Ecotourism Destinations in Romania (2016) [online]. Available at: https://www.asociatiaaer.ro/en/ecotourismdestinations/ [accessed 20 Nov. 2016]. 
The International Ecotourism Society. Principles of Ecotourism (2015) [online]. Available at: http://www.ecotourism.org/what-is-ecotourism [accessed 20 Nov. 2016].

UN General Assembly. Ecotourism key to eradicating poverty and protecting environment (2013) [online]. Available at: http://media.unwto.org/press-release/2013$\underline{\text { 01-03/un-general-assembly-ecotourism-key-eradicating-poverty-and-protecting-envir }}$ [accessed 20 Nov. 2017].

Valentine, P.S. Nature-based tourism: a review of prospects and problems. In: M.L. Miller; J. Auyong (eds.) Proceedings of the 1990 congress on coastal and marine tourism - a symposium and workshop on balancing conservation and economic developments. Newport, OR: National Coastal Resources Research and Development Institute, 1991.

Weaver, D.B. et al. The Encyclopedia of Ecotourism. Wallington, Oxfordshire: CABI Publishing, 2001.

Wearing, S.; Neil, J. Ecotourism. Impacts, Potentials and Possibilities? Oxford: Elsevier Ltd., 2009.

Wight, P. North American ecotourists: Market profile and trip characteristics. Journal of Travel Research, 34 (4), 1996, pp. 2-10.

World Commission on Environment and Development, UNWCED. Brundtland Report, "Our Common Future" (1987) [online]. Available at: http://www.exteriores.gob.es/Portal/es/PoliticaExteriorCooperacion/Desarrollososteni ble/Documents/Informe\%20Brundtland\%20(En\%20ingl\%C3\%A9s).pdf [accessed 2 Jul. 2018]

World Tourism Organization. UNWTO Tourism Highlights (2017 Edition) [online]. Available at: https://www.e-unwto.org/doi/pdf/10.18111/9789284419029 [accessed 4 Dec. 2017] 
World Travel and Tourism Council, WTTC. Travel \& Tourism Global Economic Impacts \& Issues, 2017 [online]. Available at: https://www.wttc.org/Imedia/files/reports/economic-impact-research/2017-documents/global-economicimpact-and-issues-2017.pdf [accessed 2 Jul. 2018]

Ziffer, K.A. Ecotourism: The uneasy alliance. Washington D.C.: Conservation International, 1989.

Article info: Received 06/12/17. Accepted 03/07/18. Refereed anonymously. 